\title{
Growth Hormone Releasing Hormone Measurement
}

National Cancer Institute

\section{Source}

National Cancer Institute. Growth Hormone Releasing Hormone Measurement. NCI

Thesaurus. Code C74862.

The determination of the amount of growth hormone releasing hormone present in a sample. 